\title{
Directions of Increasing the Using of the Efficiency of the Northern Sea Route as International Transport Corridor
}

\author{
Ignatyeva O.A. \\ Department of Economic Theory and Econometrics \\ Institute of Management, Economics and Finance Kazan \\ Federal University \\ Kazan, Russia \\ Oksana.Ignateva@kpfu.ru
}

Rozanova L. N.

Department of economic theory and innovation University of management "TISBI"

Kazan, Russia

ladarozanova@bk.ru

\author{
Abdullin I.I. \\ Department of Economic Theory and Econometrics \\ Institute of Management, Economics and Finance Kazan \\ Federal University \\ Kazan, Russia \\ Ildar.Abdullin@ksu.ru \\ Khadiullina Iu. V. \\ Department of Economic Theory and Econometrics \\ Institute of Management, Economics and Finance Kazan \\ Federal University \\ Kazan, Russia \\ yhadiullina@ieml.ru
}

\begin{abstract}
The relevance of this research is connected with the whole complex of the new phenomena in development of the transport system of our country and the whole world in general. The states have interests in the Arctic zone and in modern conditions perform complex scientific developments in this territory and actively interact with the purpose of achievement of joint goals based on mutually beneficial cooperation. On organizational and legal aspects of partnership of the different countries make impact in the Arctic zone multidirectional processes of international policy, especially various interests of the states in the extracting and transport sphere.
\end{abstract}

Keywords-Northern Sea Route; infrastructure; international transport corridor; cost efficiency of transportations.

\section{INTRODUCTION}

Transport strategy of the Russian Federation development of navigation in the basin of the Arctic Ocean is determined as the priority direction of state policy with unconditional preserving of national jurisdiciton of the Northern Sea Route (further NSR) and public administration by this transport system providing its icebreaking service.

The transport strategy of the Russian Federation development of navigation in the basin of the Arctic Ocean determines as the priority direction of state policy at unconditional preserving of a national jurisdiciton on the Northern Sea Route (further NSR), public administration by this transport system and providing it icebreaking service.

\section{LITERATURE REVIEW}

The whole complex of works was devoted to studying of the Arctic zone in a domestic historiography. Generally, the staff of RAS are the authors of researches. So, T.Y. Habriyeva considered the Arctic right, A.A. Dynkin devoted a number of researches to the international legal regime of the Arctic. Egorov K.A., Krasilnikova O.A., Muravyev I. P., Shpak A. L. explored the Arctic from the economic position. In a number of works of theoretical character features of transport infrastructure of the Arctic were studied and analysed.

\section{ResEARCH Methodology}

Methods of the economic analysis, graphic and cartographic methods are used in this article for achievement of research purpose. Holistic approach and a method of structural and logical decomposition of the innovation processes in the sphere of excursion services are aso applied in this research. They allowed to reveal the nature, to disclose the content and forms of realization of these processes; to prove dynamic stability of their development of travel business as key property of the regional tourist industry.

The practical importance of this work is connected with the opportunities of applience of conclusions of the author for further developments opening on its basis of researched subject. 


\section{RESULTS}

The practical importance of this work is connected with the opportunities of the author conclusions application for further developments opening on its basis of research subject.

The Northern Sea Route represents one of the most significant components of infrastructure of Far North now and provides communication between the European territory of Russia and the Far East. Without further development of its infrastructure realization of a number of the major projects for the Russian Federation is threatened.

Foreign states are very interested in cooperation in development and mineral extraction first of all of hydrocarbons. In this regard international cooperation for development of navigation in the Arctic region develops more and more widely.

In September, 2018 through the Northern Sea Route (NSR) the first container ship went through. It gave the chance to estimate the capacity of NSR in providing an alternative to traditional ways between Asia and Europe. The vessel "Venta" of Maersk Line company left Vladivostok with the freight of frozen seafood. But it brought something much bigger and considerable. The vessel not only executed container transport on the Russian cold Arctic coast. It brought hope for emergence of a new route which would allow to save time in large trade transportations and also to reduce quickly growing fuel accounts of the navigable industry. However in reality everything is much more difficult for operators of vessels. Difficulties of economic and operational character can interfere with achievement of success in this direction.

In this regard Maersk Line in summer of this year decided to send the vessel on NSR. Venta Maersk is the small 3600container ship left from Vladivostok to St. Petersburg. The vessel arrived in the destination saving 10 days of traveling in comparison with transportation through Suez. The representative of Maersk said that data collection was a purpose of visit. Now the company does not consider the Northern Sea Route "an alternative to the usual routes".

However, potential really impresses: container transports move $98 \%$ of consumer goods in the world. More expensive freights will attract big investments. It will provide a bigger number of transportations through the Arctic sea lanes.

NSR should not be considered as competitor to the Southern sea lane.

Container carriers with a capacity of 6000-14 000 TEU work on traditional southern routes. Container carriers of an ice class with a capacity of 2000-6000 TEU can be operated on NSR taking into account many factors. Thus, the specified types of container carriers are in various segments of the market by the tonnage, have various structure and level of income and expense of operation economy.

The total amount of transportations can be 1.8 million tons (140 thousand TEU). Freight dispatch frequency is two times a month. The example is time of round trip of the container carrier with a tonnage of 3000 TEU at the fixed icebreaker assistance. As it is seen from the Fig. 1 time of trip can be also around 10-11 days.

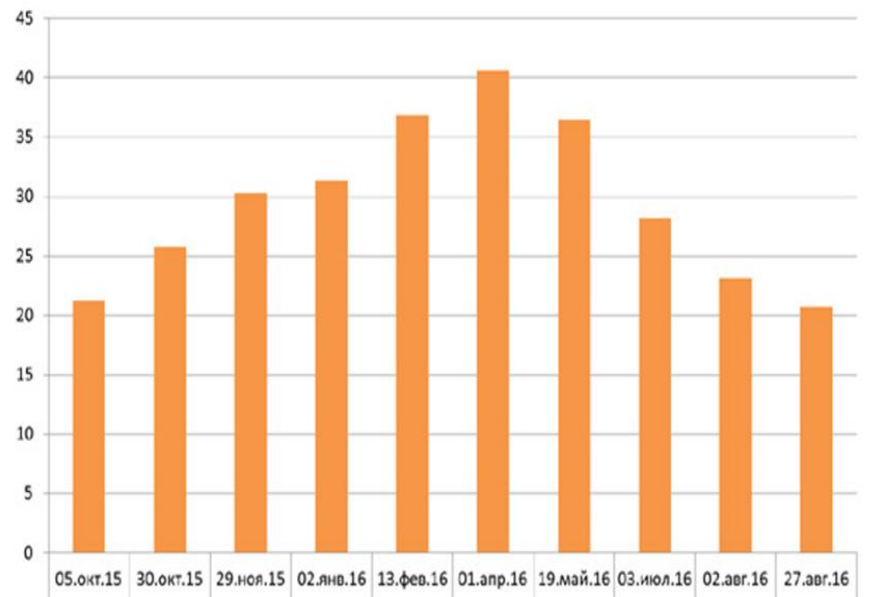

Fig. I. Time of round trip of the container carrier with a tonnage of 3000 TEU with the fixed icebreaker assistance.

According to data of calculation JSC TSNIIMF (Fig. 2), income of the container carrier of ice class Arc7 with a tonnage of $3000 \mathrm{TEU}$ at the fixed icebreaker assistance will make about $\$ 37,000,000$ for navigation, at the same time the analysis of an expensive part showed that in structure of working costs the greatest share is made by expenses on fuel from 58 to $82 \%$, the share of expenses on icebreaker assistance makes from 18 to $25 \%$ (Fig. 3). Freight cost 40 ' of a container to Murmansk will be about \$2234 which is close to the freight rate used in the above-stated calculations.

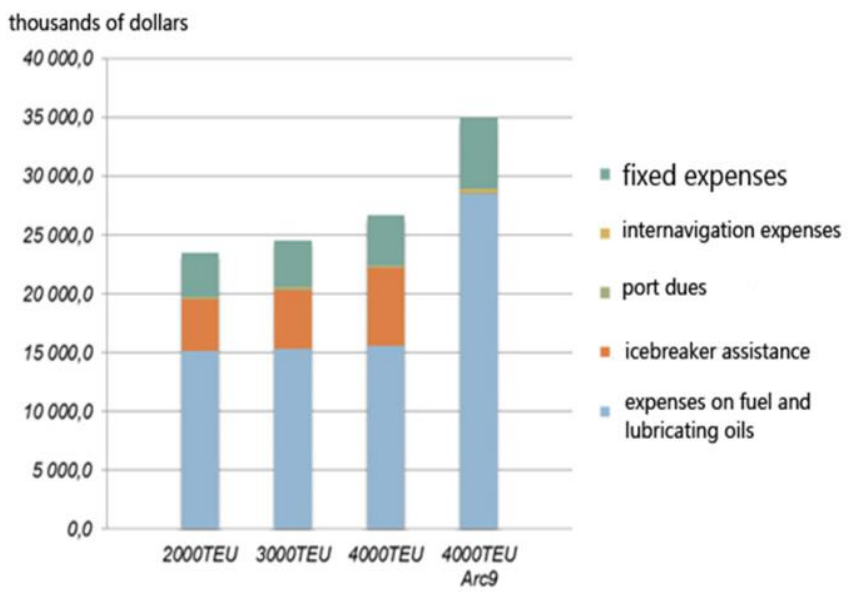

Fig. 2. Structure of working costs of basic options of vessels on the settlement line of operation 


\section{SHANGHAI CONTAINERIZED FREIGHT INDEX}

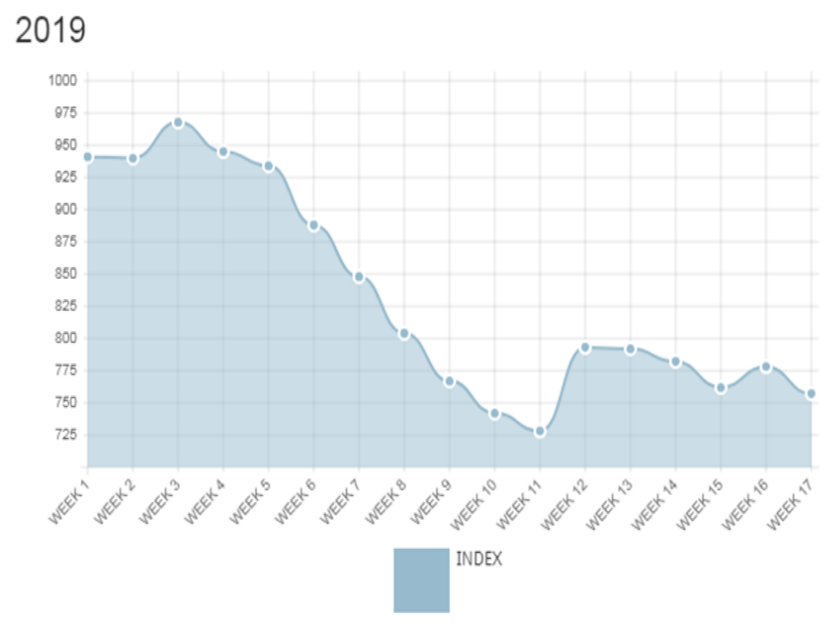

Fig. 4. Dynamics of change of the Shanghai container freight index (SCFI), 2019

\section{8}

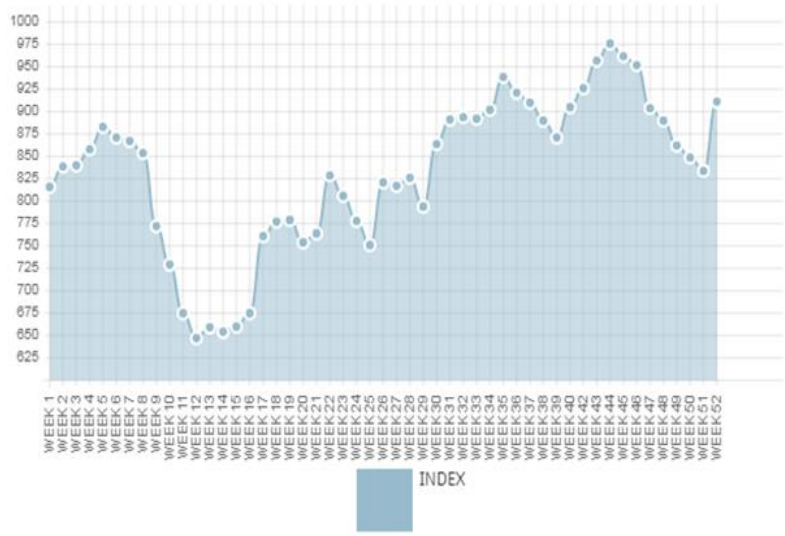

Fig. 5. Dynamics of change of Shanghai container freight index (SCFI) in 2018.

It is necessary to solve the following questions at first stage of development:

- project implementation of construction of a container terminal within complex development of Murmansk transport hub;

- design and construction of a container terminal in the port of Petropavlovsk-Kamchatsky (TOSER Kamchatka);

- construction of three container carriers of the Arctic ice class Arc7 with a capacity of 3000 TEU;

- construction of series of universal nuclear power icebreakers of the $60 \mathrm{MW}$ project 22220 (increase series up to 5 vessels);
Significant modernization of sea port infrastructure and modern container ships for the Russian fleet are necessary for project implementation of the Arctic container line. 
- creation of the uniform port operator for purchase and transportation of fish products from the Far East in the European part of Russia based on public-private partnership.

The infrastructure operator of NSR is Rosatom. Rosatom implement the project of construction of nuclear power icebreakers of new generation with the power of $60 \mathrm{MW}$ project 22220 .

The ice breaker "Arctic" will become the main, 2 more linear ice breakers of project 22220 - "Siberia" and "Ural" are under construction.

These ice breakers will start operating in 2019-2021. Construction of the 4 th and 5th ice breakers of project 22220 is planned.

The construction contract of these 2 ice breakers can be signed with Baltic Shipyard where the first 3 ice breakers are under construction already in first quarter of 2019.

Construction of the 4th and 5 th ice breakers of project 22220 will cost about 100 billion rubles.

The contract provides allocation of financing on contracting of the equipment for both vessels at once that will help to reduce order cost. The scheme of financing of construction of 2 new ice breakers of project 22220 will be shared.

Funds of the federal budget will provide $50 \%$ of expenses and Rosatom with investors will cover the rest. By 2035 the icebreaker fleet servicing NSR will include:

- 5 ice breakers with the power $60 \mathrm{MW}$ of the project 22220 ,

- 3 super-power ice breakers Leader with the power 120 MW,

- 4 ice breakers on the liquefied natural gas (LNG) with the power up to $40 \mathrm{MW}$,

- "50 years of the Victory" which resource will be exhausted in 2039.

Expected arrangement of ice breakers on NSR is given in Fig. 6.

In 2020 Rosatom is going to contract construction of ice breaker Leader. The cost of ice breaker Leader is estimated around 120 billion rubles today. There is a hope that until the end of 2019 a project will startup and will complete realization till 2020 at the plant Zvezda.

The president made the decision that the first ice breaker Leader will be under construction on budget money because risks to start first "Leader" on commercial financing too high. So far yet there is no engineering design, it has to be ready during 2019.

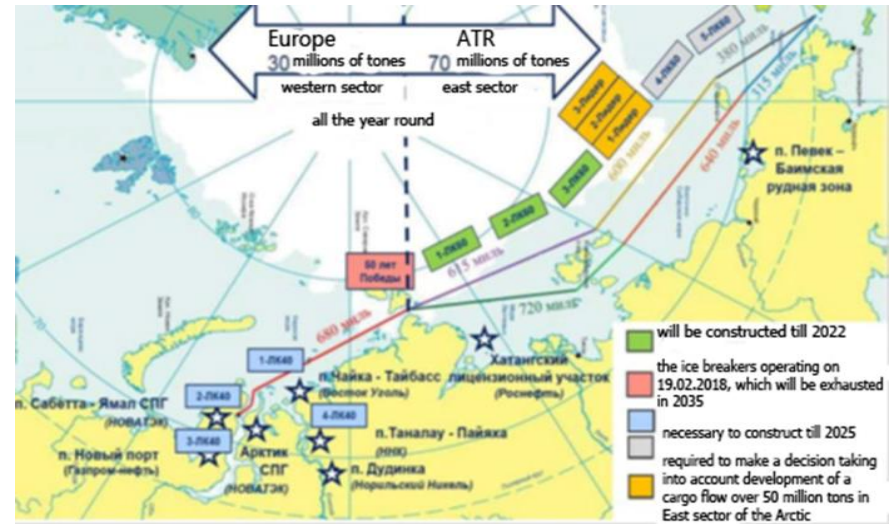

Fig. VI. Target arrangement of ice breakers of Rosatom State Corporation in 2025-2030.

\section{CONCLUSIONS}

Thus, in our opinion, development of NSR infrastructure got a good start, and with due attention of the leadership of the Russian Federation it is possible to expect in the nearest years of large-scale growth of a cargo flow volume along this route.

\section{References}

[1] Federal target program "Development of the transport system of Russia (2010-2020)". URL: http://fcp.economy.gov.ru/cgibin/cis/fcp.cgi/Fcp/ViewFcp/View/2014/264.

[2] Bartenstein K. The "Common Arctic": Legal Analysis of Arctic and non-Arctic Political Discourses. In L. Heininen, H. Exner-Pirot, \& J. Plouffe (Eds.), Arctic Yearbook. Akureyri: Northern Research Forum. 2015, pp. 264-280.

[3] Bennett M. China Plans Arctic Belt and Road Initiatives. 2017. URL: http://www.maritime-executive.com/editorials/china-plans-arctic-beltand-road-initiatives.

[4] Bennett M. China's Belt and Road Initiative Moves into the Arctic. 2017. URL: https://cryopolitics.com/2017/06/27/CHINAS-BELT-ANDROAD-INITIATIVE-MOVES-INTO-THE-ARCTIC/.

[5] East Russia Analytical Agency. Breaking the Ice. 2016. URL https://www.eastrussia.ru/en/material/breaking-the-ice/.

[6] Wong E., Chi L.K., Tsui S. \& Tiejun. One Belt, One Road: China's Strategy for a New Global Financial Order. 2017. URL: https://monthlyreview.org/2017/01/01/one-belt-one-road/.

[7] Convention of the United Nations on maritime law of 1982. URL http://www.un.org/ru/documents/decl_conv/conventions/lawsea.shtml/.

[8] Abdullin L.F. Sitdikova A.R., Battalova L.M., Garaeva O. A., Ignatieva O.A., Vasiljev V.V. Innovation in the region's business infrastructure. Publishing house: Vestfalika. 2019, 90.

[9] Alexsandr S. Kuznetsov. Russian Professor's meeting. Russian Journa of Physical Education and Sport. 2019, 14(1), pp. 17-22. DOI 10.14526/2070-4798-2019-14-1-18-24

[10] Alina R. Battalova, Oksana A. Ignatjeva. THEORETICAL FOUNDATIONS FOR THE FORMATION AND DEVELOPMENT OF THE ECONOMIC THEORY OF WELFARE. ISSUE: Multidisciplinary Social Science \& Managementю 2019, vol. 10, S1, pp. 28-31 